\title{
Database Marketing IN Life Insurance Marketing Development Strategy
}

\author{
Guozhen Sun ${ }^{1, a}$ \\ ${ }^{1}$ Jilin radio and TV University, Changchun City, Jilin Province, China \\ a18791138@qq.com
}

Keywords: Database marketing, Life insurance marketing, Development strategy

\begin{abstract}
This template explains and demonstrates how to prepare your camera-ready manuscript for publisher. The best is to read these instructions and follow the outline of this text. Please make the page settings of your word processor to Letter format (21.59 x $27.94 \mathrm{~cm}$ or $8.5 \times 11$ inches); with the margins: bottom $2.8 \mathrm{~cm}$ (1.1 in) and top $2.8 \mathrm{~cm}$ (1.1 in), right/left margins must be $2.54 \mathrm{~cm}$ (1 in). Your manuscript will be reduced by approximately $20 \%$ by the publisher. Please keep this in mind when designing your figures and tables etc.
\end{abstract}

\section{Introduction}

Database marketing is a kind of big data marketing mode based on information technology and network technology. It originated in the 80's of last century, it has developed with the gradual maturity of the market and the increasing competition of the enterprises. Database marketing mode is the combination of customer relationship management and database technology, and the current customers for a comprehensive and systematic search and analysis, in order to achieve the purpose of business growth. From the point of view of the concept of database marketing, database marketing model generally consists of data acquisition, storage, processing, customer mining, data usage and improvement of links and according to the characteristics of the customers for the judgment the implementation of marketing, also reflect the customer promptly change trend, so as to improve marketing efficiency.

\section{Principles of Database Building}

Principle of reference. Life insurance companies use database marketing approach can greatly improve the sales of life insurance products, but conceptual database in use process to according to the actual situation of the life insurance companies, can be used for reference for other enterprises, but not scripted.

Principle of flexibility. Life insurance companies in the construction of life insurance database, it is necessary to ensure the database is established to meet the needs of the current database marketing, but also to enable it to bear the demand of enterprise strategic transformation in quite a long period of time.

Principles of classification. The database classification is conducive to the life insurance companies to exchange and information analysis, but also for the marketing team to provide more accurate marketing data, to promote the life insurance companies to improve the overall level of efficiency.

\section{Analysis on the Present Situation of Life Insurance Marketing in China}


China's current market situation is greater than the demand for supply. Customer is not only the core of enterprise development, but also the key to improve economic efficiency of enterprises. Therefore, enterprises in order to maintain long-term development, in the process of operation must actively explore new customers, consolidate old customers, and long-term cultivation of loyal customers. China's current life insurance marketing is the main mode of agent marketing, but there are many problems in the development, such as the lack of customers, the loss of old customers, loyal customers, such as precipitation phenomenon is more serious.

Lack of customer accumulation. In the life insurance marketing process, prospective customers accumulation and the amount of signing has the most direct relationship. The main reason for the decline of life insurance agents in our country is the lack of the list of prospective customers. In this situation, even if life insurance companies have a good management mode, it is difficult to have a good effect. Although China's life insurance companies in the process of marketing has been more emphasis on the accumulation and training of prospective customers, but these methods and training can not effectively solve the problem of quasi customer accumulation at the present stage.

New customer development is not reasonable. In the traditional agent marketing mode, the level of business volume is the amount of signing agent business. In the past, life insurance companies have adopted this marketing model to implement business expansion, but also formed a certain scale of business income. But on the current development of the point of view, continue to use agent marketing model for new customers to develop, will have a lot of limitations. Because with the development of the market, the new customer development has entered a need to cross industry, cross age, cross career implementation of the stage of development. In this need to carry out market segmentation and the need for the development of the target customer positioning development trend, only rely on the agent's personal strength to carry out customer development is far from enough.

Too much control over customers. In the traditional agent marketing model, the commission agent, hard work. Although this commission system to a certain extent, stimulate the enthusiasm of the agent, but because the agent and the customer is not a labor contract, so the professional sense of belonging is relatively low. In addition, due to the problem of the system, the agent team turnover rate is relatively high, the mobility of talent is relatively large. In the insurance industry, the relationship between the agent and the client is very close. If the agent to take refuge in other companies, the general will be taken directly to customers. And for those who have not been taken away, the general will be included in the company's customer service, that is, to lose the right to have an exclusive agent to become an orphan policy.

\section{Application of Database in Customer Analysis}

Transformation of customer data. At present, our country many life insurance companies will to customer information in customer service for unified management, including customer purchase policy number, type of insurance, customer basic information, customer insurance date and customer change insurance and surrender. The company will be a unified customer information management and transformation, and the transformation of customer information into the database, and then the information processing and analysis in order to better understand the customer and customer service.

Exchange of customer data. In database marketing model, life insurance companies should in the sales process actively looking for value, the qualification of the enterprises to establish strategic cooperative relations and will be reasonable, scientific and standardized exchange owned by the 
enterprise customer information, so as to realize the sharing of customer resources. , of course, life insurance companies and other enterprises in the process of cooperation must adhering to the principle of reciprocity the principle of mutual benefit, fairness and good faith, and with these customers to maintain long-term strategic cooperation relationship between joint, as far as possible don't violate the wishes of customers, but can not damage the interests of customers, with customers to establish a good long-term relations of interests.

Purchase customer information. In the database sales model, the purchase of customer information is also a positive and effective way to obtain the information of potential customers. This method can help the life insurance companies to establish and enrich their enterprise database resources at a faster speed. Of course, the purchase of customer information in the so-called purchase must be based on the legal, compliance, and at the same time need to pay attention to the privacy of customers can not be leaked.

Customer retention analysis. In the process of life insurance sales, on the one hand to the old customer information and insurance record system for registration, on the other hand to some potential customers information for rational analysis and find its not in the insurance company. For guaranteeing the customer, should pay attention to the analysis of guaranteeing customers not to buy insurance, and actively understand the acquisitions of its insurance in the same industry; to high-quality customers, to determine the criteria for the classification of the customers with quality and efficient information, further analysis quality of customer retention rate, and the use of the advantage of database marketing will be the loss of quality customers pull back, and establish a close cooperative relationship.

\section{Database Marketing Development Strategy in Life Insurance Marketing}

Promoting the strategic transformation of the database marketing of life insurance companies. Database marketing is a new strategic marketing model, which is based on information technology and the era of big data, an innovative marketing model, and the traditional agent marketing model is very different. Specific performance in: first, customer list and data will by the unity of the life insurance companies to agents in the hands of that life insurance companies to agent organization plan and purpose of life insurance product sales, and sales agents on the implementation of monitoring and analysis. Secondly, database marketing mode can the life insurance customer for unified management, simplify the working process of the marketing agent, reducing agent tasks, and discard the agent accumulation customer's personal behavior problems. Again, the use of database marketing can also be transferred to the life insurance agent training focuses on marketing skills, so that the agent can be more concentrated and professional product sales. Finally, database marketing can change the traditional human sea tactics of life insurance marketing, which is beneficial to the life insurance companies to develop new agent selection criteria, to improve the ability and comprehensive quality of the agent business.

Improve the life insurance marketing support system. The life insurance enterprise uses the database to carry on the life insurance product marketing, needs to have the more marketing support system and the coordination, therefore the life insurance enterprise needs to carry on the redesign to the original marketing support system. First of all, the life insurance companies need to allocate customer resources reasonably, and to effectively evaluate the sales skills and skills of the agents, and establish a strict hierarchy. Secondly, the re enactment of the Commission distribution system. After implementation of database marketing mode, the life insurance agents in many cases are based on life insurance companies to provide customer database list of marketing, because of its 
access to the resources provided by the company, so be sure to according to the of the new commission charges distribution of benefits. In addition, in the agent's performance appraisal, it is necessary to according to the agent to use the database list of grades and the number of the assessment, but also according to the agent of the customer database development situation, service quality and policy of the quality of a comprehensive assessment and analysis, comprehensive evaluation of generation product marketing ability.

Pay attention to the innovation of sales model. The implementation of the innovation strategy is not only to see its value, but also to see the difficult task and the difficulty of the operation. First, life insurance companies in the process of database application must do forward-looking analysis, establish a scientific life insurance database resources, do promote both the development of life insurance marketing database, and can carry out the reform and innovation of the better. Second, actively respond to changes in the sales process. The application of database marketing mode changes the way of the life insurance customers, and also changes the way of the life insurance company's management and the working mode of the agent. Therefore, after take database marketing, life insurance companies need to develop comprehensive reform program, such as the construction of new marketing process and marketing system, develop the new distribution of benefits programs and training management regulation, adjust enterprise development strategy and the benefit evaluation mechanism and so on.

At present, the traditional agent marketing model has indeed been serious not adapt to the development of China's life insurance market, and according to the international life insurance market development experience and rules, database marketing model will be an effective solution to properly solve this kind of problem. Of course, database marketing model changes will not happen overnight to complete the things we can learn from the useful experience of foreign countries, but must not be brought on by, which is China's life insurance enterprises need according to their own situation and explore the depth of the major issues.

\section{Reference}

[1] $\mathrm{Fu}$ Jie. Innovation strategy of life insurance marketing: database marketing [J]. insurance research, 2011,05:77-82.

[2] Wang Xiujuan, Peng Yongjia. Life insurance marketing innovation in County insurance [J]. technology and innovation, 2014,03:83-84.

[3] Li Fuquan. Study on the performance management of the marketing system of life insurance enterprise [D]. Wuhan Institute of Technology, 2014

[4] Sun Naiyan. Study on the innovation of marketing mode of life insurance with Chinese characteristics [D]. Northeast Normal University, 2012

[5] Wang Hongtao. Study on the efficiency of insurance customer relationship management [D]. Nankai University, 2012 